\title{
STUDY OF PECULIARITIES OF LAND RELATIONS THROUGH THE PRISM OF ECONOMIC THEORIES
}

\author{
Vasyl Moroz \\ Department of Finance named after S. I. Yuriy \\ Ternopil National Economic University \\ 11 Lvivska str., Ternopil, Ukraine, 46009
}

\begin{abstract}
The paper defines the essence of the notion "land relations" and outlines their main peculiarities, based on the analysis of scientific works of classics of the world economic thought, study of the historical experience and consideration of practical aspects of lands resource use in economy. Negative results of the influence of the neoliberalism theory on the formation of land relations in Ukraine and the former USSR countries after getting independence are substantiated. Attention is accented on a necessity of taking into account national interests at reforming land relations.

The aim of the paper is to study peculiarities of land relations through the prism of economic theories, taking into account their development evolution, and formation of the complex approach to defining the essence of the notion "land relations" as an object of financial-economic regulation.

The methods of empirical and retrospective analysis of the world and native economic thought was used in the paper for separating fundamental bases of land relations; the methods of generalization and comparison of scientific approaches as to defining the essence of land relations and their elements; system approach for substantiating the economic base of land relations, determination of their elements and principles.

Key peculiarities of land relations, complexly discovering their essence, taking into account a necessity to create an effective economic-legal mechanism of their regulation within the conflict of the neoliberal economic ideology and national interests have been formulated. There has been offered a wide approach to understanding an object of land relations that is land resources; it has been proved, that realization of all legal actions with land resources results from a necessity to observe the factor of lands suverenization; the economic base of land relations has been substantiated; principles of land relations, resulting from a necessity of the rational land use, observance of national interests and guaranteeing of food safety of the state, have been outlined.
\end{abstract}

Keywords: land relations, land resources, land rent, land market, land lease, land use.

DOI: $10.21303 / 2504-5571.2020 .001428$

\section{Introduction}

The entrance of Ukraine in the next economic crisis, conditioned by internal system unbalances and negative external shocks together with manifestations of force-major circumstances, connected with COVID-19 pandemic, actualizes a necessity to review existent conceptions of the formation of effective land relations and their financial regulation again. One of main aspects in this sphere is solving problems, connected with land market introduction, guaranteeing of the rational land use that increases the demand for complex scientific studies of the outlined problems.

Taking into account deindustrialization and establishment of the agrarian order of the native economy, solving of existing problems as to the necessity of land market introduction, organization of its functioning, development of effective levers of financial regulation of land relations and use of financial-juridical safety devices against the foreign expansion is a complicated scientific-methodological problem, which solution needs a complex multi-disciplinary scientific approach to land relations definition at the essential level.

Works of a series of native scientists are devoted to problems of land relations organization and regulation in Ukraine. Especially, it is worth to pay attention to the studies of native scientists O. I. Gutorov and M. Y. Yaruda [1], who consider problems of land relations in Ukraine through the prism of establishment of long-term lease relations at the stage of land market formation. The scientists substantiate the expedience of deregulating the sphere of land lease for raising the lease transparency level, creating possibilities for attracting credit resources on bail of the right to land lease and emphyteusis. But the scientists use too much limited approach to explaining causes of a low rent, motivating it only by the absence of free land market of agricultural destination, neglecting such causes as a low level of economic development in whole, low internal demand and 
monopolistic competition at local markets of land lease and so on. The scientist M. M. Timoshenko [2] based her research of land relations in Ukraine on substantiating the effectiveness of such forms of land relations realization that may exist at the absence of land market, especially: land cultivation on the lease rights, personal (family) land cultivation, collective cultivation. The contribution of the scientist is worth attention in the aspect of creating conditions for preserving national interests as to food safety, territorial integrity and suverenization of lands and also in the sphere of substantiation of the importance of family farming and cooperative movement development on principles of the collective economic form. At the same time aspects of determining the essence of land relations in the aforesaid works are not elucidated that accents their fragment character. Among other Ukrainian scientists, concentrating attention on the improvement of land relations, it is worth to note such researchers as V. A. Lomakovych, T. E. Unkovska, V. M. Ilchenko, T. V. Bogdan [3], who one of firsts in Ukraine dealt with problems of land grabbing - capture of lands of other countries by using doubtful methods of foreign investment that allows to consider results of free realization of land market of agricultural destination from the point of view of not only positive aspects, but also through the prism of violation of national interests and neocolonialism tendencies under the pretense of neoliberalism. Such idea is followed by the scientists O. V. Khodakivska, R. Levek [4], who also touch the problem of land relations regulation under condition of domination of the liberalism doctrine, at the same time they pay not enough attention to making arrangements for defending national interests, stimulating a support of farming and competitiveness of a national producer, guaranteeing of the rational land use and so on.

The study of the native scientists O. O. Nepochatenko, S. M. Kolotukha, P. M. Borovyk, B. S. Guzak [5], who consider land relations from the position of financial background for their development, including through creation and use of special land mortgage banks are worth attention, but the authors in their work not elucidate possible risks from giving land of agricultural destination as a bail to banks with a foreign capital.

In the modern world economic thought in the part of land relations study the work of the scientists M. Cai, I. Murtazashvili, G. Murtazashvili [6], who put the main accent on state protection of the proprietary right for land as a social good, manifested through the effectiveness of institutions, is worth attention. Just institutions as game rules in a society, based on rules and traditions, determine development directions of land relations and are their base. This research gives a possibility to understand that even the free land market of agricultural destination is based on legal regulations, acting as safety devices of "market gaps". A consideration of land relations through the prism of neomercantilism, offered by the scientists P. Belesky [7], A. Banergy and E Duflo [8], who deal with problems of getting food safety in the context of free market land of agricultural destination, is rather interesting. A special accent is made on the development of land relations in the context of food safety guaranteeing under condition of the multi-polar international order and multi-polar global food system. The aforesaid works widen the research object of land relations essentially, substantiating their entrance at the international level that, from our point of view, must raise the importance of taking national interests into account in the context of reforming land relations in Ukraine.

At the same time for today there is no unity in approaches to solving land relation problems from the point of view of instruments of guaranteeing food safety and sustainable development, following from conceptions of free market or protectionism, because today the subject character of economic science that reflects scientists' belonging to one or other scientific schools or ideologies, comes in the forefront.

That is why the aim of the paper is to study peculiarities of land relations through the prism of economic theories, taking into account their development evolution, and formation of the complex approach to defining the essence of the notion "land relations" as an object of financial-economic regulation.

\section{Materials and methods of research}

Scientific understanding of land relations and mechanisms of their regulation in the modern scientific thought started after getting independence by Ukraine and putting the question about 
denationalization of lands of agricultural destination to the agenda. But based on the analysis of scientific works in the field of law, we can make a conclusion about a certain excess of the theoretical load of the modern economic science, where fundamental scientific conclusions are formed, based on logic and semantic analysis of existing basic notions, including one of "land relations". Paying excessive attention to conclusions, obtained from an analysis of definitions of notions and economic categories, offered by different scientists, the native economic science sometimes neglects just such important principles of economic theory as collection of facts, their systematization, use and conclusions that A. Marshall described in his time in the work "Principles of political economy" [9]. That is why, from the point of view of the author of this paper, studying the essence of land relations must be started, first of all, not from analyzing definitions of well-known economists, but from considering peculiarities of social relations as to land use, beginning from primordial times.

As it is testified by historical facts, the development of land relations started from the rise of farming and lands cooperation in communities, ancient settlements, cities and then - in states. The process of lands cooperation provided their suverenization that is the power of a community, city, feudal lord or state covered cooperated lands, and all operations with them (sharing, donating, selling) were realized exceptionally within existed rules and power. Suverenization of lands at the terminological level was first offered in the Westphalia peace treaty, signed in 1648 [10, p. 132], by defining a term "territorial sovereignty" that meant obligations of states to observe the principle of territorial integrity.

The process of lands suverenization formed bases for establishing key legal acts of land relations: possession, use and management. But existent definitions of the term "land relations" don't give any meaning to the principle of land suverenization and this, in its turn, results in the formation of preconditions as to false understanding of land relations and rise of shade operations with land. In practice, realization of legal acts of possession, use and management in states with weak legal institutions and low level of the ability to defend own sovereignty results in state disintegration, liquidation of proprietary rights or establishment of external power or management as it is for today in Madagascar, Indonesia, Philippines [3] and other countries, where facts of land grabbing take place [11].

This idea may be confirmed by definitions of the notion "land relations", given in works by V. M. Ermolenko, who defines them as social relations on possession, use and management of land plots and transfer of these competencies to other persons [12, p. 10]. But it must be noted, that the author gives rather general definition that reflects operations with land as with a usual commodity without any concern to territory, territorial integrity, state law and public good.

The Ukrainian scientist M. M. Fedorov understands land relations as social ones as to possession, use, management and disposal of land at the state, regional, economic and internal economic levels as an object of economy and production means in agriculture [13, p. 4]. But in this definition attention is accented exceptionally on lands of agricultural destination as objects of agricultural activity.

Although, returning to causes of rising land relations, let's note such a fact: most military conflicts at previous development stages of the human civilization took place just for land resources. Thus, among most known military conflicts for land resources, we can cite: Sicilian rebellion in the period of reforms of Gracchi brothers (130-120 BC), Peasant was in Germany (1524-1526), Taiping rebellion in China (1850-1864). According to data of the United Nations Organization, for the last 60 years $40 \%$ of military conflicts were also for natural resources, including generous lands [14]. At that let's note that so-called "hybrid" wars for resources are not counted at all.

So, we think that understanding of the essence of land relations must be based on obligatory taking into account their basic objects - land and land resources. A complex definition of land resources is given by the Ukrainian scientist Z. P. Pankiv, who thinks that land resources are the most important part of the natural environment, characterized by spatial location, relief, soil cover, flora, bowels, waters, is a main means of production in agricultural and forest economy and also a space basis for placing all economic branches [15, p. 7].

Physiocrats F. Kene and A. Turgot, who first in economic science considered a question about an origin of added value in the production sphere and considered agricultural labor as only 
production one, and nature and natural properties of land as a single source of wealth, first gave land relations the economic character (together with legal) [16, p. 407; 578].

But in professional economic literature, W. Petty, who studied salary and rent as parts of a value, created by labor, from positions of the labor theory of value, is considered as a forefather of the doctrine about land rent. According to him, rent in a natural expression is a part of a product, remained after deduction of a salary and seeds. Analyzing land rent, he comes to the definition of land price, determining it as a sum of annual rents for 21 years - time of common life of three generations [17, p. 24].

A special place is occupied by the doctrine about rent in the fundamental work by A. Smith "Study about nature and causes of nations' wealth", where "rent, considered as a fee of land use, is naturally the highest sum, can be paid by a leaser, taking into account a land quality. Setting agreement terms, a land owner tries to leave a land leaser only such part of a product that is enough for compensating the capital, spent for seeds, cattle purchasing and keeping, and also other agricultural instruments, and for getting profit for the capital, invested in agriculture, usual for this area... a land owner naturally wants to get as a land rent all that part of a product or the same part of its price, remained over this part (invested in agriculture as a capital - author)" [18, p. 120]. So, A. Smith understands land rent as a part of income that exceeds investments in agricultural production.

Considering rent depending on lands location and fertility, A. Smith accents that the base of land relations is not only agricultural lands, but all land resources, because: "a rent (if a plot is placed near a sea -author), obtained by a land owner, corresponds not to something, can be obtained from the land by a farmer, but to something, can be obtained from the sea and the land together" [18, p. 121].

An important contribution in studies of land rent was made by the famous economist D. Ricardo, who defined rent as "a part of a land product, paid to a land owner for using initial and non-destructed soil forces" [19, p. 65]. D. Ricardo thought that rent appears as a result of including land in cultivation together with using such production factors as labor and capital, because "...nobody will pay for land use, if there is a lot of land, not turned into property that may be used by anyone, who wants to cultivate it" [19, p. 68]. According to the scientist, a rent doesn't determine a commodity price, and a price level reflects its size: "If a high price of bread was a result, not a cause of rent, its price would vary proportionally to an increase or decrease of rent, and rent would be a part of price. But as far as a regulator of bread price is bread, produced at maximal labor consumption, rent is not included, and cannot be included even to the least extent in its price as a component" [19, p. 69]. Thus, Ricardo's rent theory reflects most complexly the value of land resources, which limitation and quality determine a land rent size.

Together with D. Ricardo, A. Smith, F. Kene and W. Petty, it is also worth to note a contribution in the development of the doctrine about land rent and land relations by G. Mille, who first accented that all increments of rent income, related to a certain basic year, may be excluded as tax without great losses [20, p. 77]. Thus, it may be concluded, that G. Mille in his politeconomic work "Bases of politic economy with certain additions to social philosophy" substantiated a necessity to implement land tax at the scientific-theoretical level.

Thus, based on the brief analysis of main directions of the scientific study of land relations and land rent in the works by the representatives of the classic school of economic theory, let's note that the formed theories of land rent became the beginning of separation between the legal and economic fundaments of land relations formation, because classics formulated such their main attributes as land rent, land tax and land price.

Together with it, in the context of economic understanding of land relations bases, it is impossible not to remind the doctrine by K. Marx, who analyzed an importance of land for social production and separated two notions: land-matter and land-capital. The first one must be understood as a land (space), appeared in the process of its evolution development, not depending on human will and consciousness, and was a place of human settlement and existence source. From the moment, when land in the process of development of the human society, becomes a production means, it acts in a new quality - capital, which a labor process is impossible without, “... because it gives a worker locus standi [a place of standing], and its process - a field of employment)” [21, p. 172]. 
Including land to capital, K. Marx substantiates preconditions for the development of crediting producers on bail of land. At the same time the scientist pays attention to the fact that land-capital is not eternal, and has the ability to amortization as a working capital [22]. That is, K. Max's views are literally focused on the necessity of rational use of land resources that are a part of land relations.

Considering land relations through the prism of post-classic economic theories, we agree with an idea of the famous Ukrainian scientist A. S. Galchinsky, who notes: "Economic science is not autonomous, but always reflected, reflects and will reflect in its arguments integral processes, taking place not only in the economic sphere, but in whole society, in the modern world development in general" [23, p. 23]. Really, starting from 1910 years, economists have concentrated their attention on studying results of the second industrial revolution, a role of central banks in the economic development, overcoming of results of the crisis, caused by the two world wars and Great depression. It is confirmed by the fact that we cannot see systematized ideas about land, land relations and their regulation in two most famous works of XX century - "General theory of employment, interest and money" (G. M. Keynes, 1936) and "Capitalism and freedom" (M. Friedman, 1962).

Nevertheless, the doctrine by M. Friedman is a part of the theoretical conception of the Chicago economic school that together with other economic schools of neoliberalism was a mainstream in the economic science of the end of XX century. M. Friedman's ideas of monetarism that are in vindication of principles of non-intervention of state in economic functioning, stimulation of free entrepreneurship and priority of money-credit policy in the sphere of market relations regulation are a base of the neoliberal theory of free market. Other representatives of the Chicago school (F. Knight with his conception of perfect competition and general balance, R. Lukas with the theory of rational economic expectations and E. Fama with the theory of effective markets) continued the development of the libertarian ideology. At the same time, it is worth to note representatives of the Austrian economic school L. von Mises and F. von Hayek, who were also adherent to the liberal principle «laissez faire». But, based on the analysis of scientific views of these outstanding economists, we can make a conclusion that their support of liberalism is connected not with forming a new theory with a correspondent verification for vitality, but with searching oppositions to socialism, keyensianism and the doctrine of "the state of general welfare".

Thus, based on the doctrine of representatives of different directions of liberalism in the context of land relations construction, the applied economic theory obtained recommendations as to obligatory introduction of the free land market. The peak of neoliberal ideas was in 80-90 years of XX century, and recommendations of their representatives began to be used actively by former consultants in the countries of the former USSR. In this context it is impossible not to note a warning of the American scientist W. G. Samuelson: "It is generally accepted, that economic thought as a whole is penetrated by ideology... Ideology directs and forms thinking and scientific analysis" [24, p. 72]. That is we talk about the fact that neoliberal ideas were used by the developed countries of the world (especially USA) for redistributing spheres of influence on the former Soviet Union countries within such ideological conceptions as the Washington consensus, conceptions of neocolonialism and obtrusive individualism. Within these ideological conceptions the main accent was made on stimulating the fast transfer of former planned economies to the free market. Taking into account the intensification of the food safety problem in the world, recommendations as to free land market creation are determining for the developed world countries with limited land resources.

But it must be noted, that representatives of the Chicago economic school in their theoretical conceptions didn't deny a certain intervention of state in economy. Thus, M. Friedman in his book "Capitalism and Freedom" notes: "A state that supports law and order determines proprietary rights is for us a means for modifying proprietary rights and other rules of the economic game, makes arbitral decisions about different interpretations of these rules, provides observance of contracts, favors competition, provides the credit-money system, counteracts technical monopolies and overcomes "external effects" (enough important, from the general point of view, to justify a state intervention), acts as an additional system as to private benefaction and family in the sphere of protection of incapable people (either out of mind or children) - such state, undoubtedly, realizes 
important functions. A consistent liberal is not an anarchist" [25, p. 44]. So, neoliberalism in the pure scientific-theoretical interpretation argues for effective state and effective market.

Constructive propositions of neoliberalism are presented by the representative of the Freiburg school of ordoliberalism L. Erhard, who thought that the main role of state in the base of an economic system is in establishing free market economy and competitive market; an economic order doesn't form by its own, it must be established by the state; the state must set rules of behavior and introduce them into life actively, and not to realize the economic-production activity; an important function of a state is to elaborate and to implement the social policy - this policy must be directed on establishing the economic, social and political order [26]. In the context of our study, based on L. Erhard's conclusions, land relations in general and land market functioning in particular must be realized within outlined game rules and economic order.

At the same time, it is worth to pay attention to the doctrine of one of representatives of the Chicago school, founder of neoinstitutionalism, R. Coase, who substantiated an importance of proprietary rights in the context of providing the effectiveness of market by reaching null transaction costs that is also popular in aspects of economic recommendations as to constructing land relations on market principles.

Based on the theory by Coase [27] adherents of the neoliberal theory try to explain the market effectiveness under condition of steadfast observance of the proprietary rights and decrease of a state intervention in economy that are the base for reaching null transaction costs. But let's opportunely note that conclusions about the necessity of total non-intervention in the activity of markets and market mechanisms as a guarantee of the transaction costs decrease and market effectiveness increase, is rather idealistic. It especially concerns the land market, because a role of political transaction costs is big at it, as far as land resources cannot be renewed, created again as goods, be transferred to another place, in such a way violating the state sovereignty.

From another side, we find it necessary to accent a great role of informal institutions in market economy in general and in the sphere of land relations in particular that, according to the institutional theory, represent established customs, traditions and norms of moral behavior of economic agents. The role of informal institutions in economy is rather neatly elucidated by the one of most outstanding representatives of the neoinstitutional theory, Nobel prizewinner D. North: "The way of economic functioning is determined by the mixture of rules, informal norms and mechanisms that fix them. If rules can be changed in one night, informal norms change gradually, but just they give "legitimation" to the system of rules" [28, p. 7-8].

Land relations as social relations as to use and management of land resources are based just on informal institutions, because just established traditions of land use became a base for forming formal institutions (laws). A bright example of it is the development of land relations in the United States of America, when land laws were adopted by the principle "up from below", because squatters, who mastered American lands by the custom law, established such relations before adopting laws. Informal institutions in Ukraine have the long history of formation, starting from the times of Kyiv Rus and continued by one of first democratic agricultural republics in the world, Zaporizhzhya Sich, development of the cooperative form of economy at the end of XIX - beginning of $\mathrm{XX}$ century. Their base is traditions of peasant property for land that were rather much distorted as a result of many years of the serf right and seventy years of collectivization. But traditions of land cultivation and use are rather strong in Ukraine, sometimes despite a lack of financial possibilities of peasants and small farms for buying even agricultural implements.

In this context it is worth to pay attention to the research of the well-known economist $\mathrm{H}$. de Soto, who states in his book "The mystery of capital. Why capitalism wins in the West and nowhere else" that "resources of post-soviet countries and ones of the third world have an imperfect form: houses are built on the land, the rights to which are not properly fixed; enterprises are not juridically registered, and their responsibility is not defined; production is placed, where it cannot be seen by financiers and investors. As far as proprietary rights are not properly fixed, these assets cannot be transformed into capital, sold beyond a narrow circle, where people know and trust each other, used as a bail for a credit or as a share in investments. On the contrary, in the West each type of stationary or moving property is reflected in a document about property that is a visible top of 
the great hidden process, connecting all these assets with other economy. Due to this reflection, assets can live an invisible life alongside with the material existence. They can be bails for a credit, objects of the realty market and so on" [29, p. 75].

We agree with H. de Soto's ideas that the property right for land must be properly formed. But in the West there are strong formal and informal institutions that just function very well as a "night guard" together with the free market and specified property rights. When raider cases take place, when correspondent safety devices against lands monopolization from national and foreign investors are absent, and the population has no possibility to give the right to land as a bail for a loan on mortgage for $1-2 \%$ of annual percentage, any analogous liberal recommendations will not be effective. Because really, deregulation may be effective, when formal and informal rules of social relations organization are effective, but the duration of the deregulation effectiveness will be so long as mental models of agents of social relations retain their opportunistic behavior.

\section{Research results}

Having considered legal and economic grounds of land relations, we find it necessary to pay attention on two more important moments that will add the complexity of the theoretical substantiation of the essence of land relations, namely: ecologization of lands and food safety of land relations' participants.

Land resources that are the object of land relations are created by nature, their renovation is possible but extremely slowly (according to data, of soil scientists, 50-100 years are needed to renew $1 \mathrm{~cm}$ of a soil layer). At the same time as a result of the influence of natural, technological and chemical factors, the quality of soils, forest cover, meadows worsens that finally may cause the loss of their fertile properties. That is why the property right to land and its use requires a thrifty attitude to land resources and technological conduction of farming for keeping soils fertility at the proper level, saving their value for owners, users and economic-food potential of the state.

The growth of the globe population, widening of urbanization, negative results of global warming manifestations inevitably will result in the lack of food, and this, it its turn, actualizes a necessity to construct land relations exceptionally within national interests, taking into account the necessity to provide food safety of the country. Based on these conditions, the developed countries of the world continue to impose the free market ideology in countries with low-effective legal and economic institutions by controlled international financial-credit organizations and scientific institutions and establish elements of external management, stimulating the development of land relations towards creation of possibilities for foreign economic expansion, using poverty of such countries as Ukraine, Mongolia, Philippines, Madagascar and other ones, rich in land resources. That is why the authors are convinced that the native scientific thought must create a basis for the effective construction of land relations, taking into account the necessity of maintaining national interests and food safety of the country.

Summarizing the aforesaid, let's note key peculiarities of land relations complexly discovering their essence, taking into account a necessity to create an effective economic-legal mechanism:

- the object of land relations are land resources as a part of the natural environment, characterized by spatial location, relief, soil cover, flora, bowels, waters;

- realization of all property forms for land resources, expressed in possession, use and management of land of agricultural and non-agricultural destination, is within the national sovereign territory according to formal and informal legal and economic institutions;

- land rent, land price and price of the right to land, land tax, land-capital, land market and market of the right to land lease form the economic base of land relations;

- land resources, created by nature, are limited in space, are renewed extremely slowly, so the rational and technological land use is the main condition of the ecological principle of land relations realization;

- land resources as the territorial, economic, political and social basis of the society development are the national wealth, so its use must correspond to national interests and food safety of the country. 
Thus, based on the aforesaid, we can make a conclusion that land relations are the totality of social relations as to possession, use and management of land resources within the sovereign territory of a state, formal and informal institutions, based on principles of rational land use and support of national interests.

\section{Conclusions}

The study of the theoretical conceptions of land relations formation gave a possibility to make a conclusion that land relations are the complicated social-economic category that combines in itself elements of legal, economic, social, political and ecological relations that, taking into account the importance of land resources for the existence of states and their citizens, needs formation of the effective regulating mechanism, directed on supporting national interests in this sphere.

Based on the modern economic order development of the world, threats of food safety violation and hybrid conflicts in the sphere of land relations, we find an analysis of financial levers of land relations regulation a promising research direction, taking into account the necessity to create conditions for the development of the innovative agriculture, preservation of soils fertility, territorial sovereignty and overcoming of the food crisis in the world.

\section{References}

[1] Hutorov, O. I. (2017). Orendni vidnosyny - yak hnuchkyi instrument zemlehospodariuvannia v period stanovlennia rynku zemli v Ukraini. VSNAU. Seriia «Ekonomika i menedzhment», 4 (71), 81-85.

[2] Timoshenko, M. M. (2019). Scientific and organizational bases for improvement of land relations in the context of sustainable socio-economic development of agricultural territories. The Journal of Zhytomyr State Technological University. Series: Economics, Management and Administration, 1 (87), 36-41. doi: http://doi.org/10.26642/jen-2019-1(87)-36-41

[3] Lomakovych, V., Unkovska, T., Ilchenko, V., Bohdan, T. (2019). Rynok zemli: isnuiuchi zahrozy dlia Ukrainy ta neobkhidni zapobizhnyky. Analitychna dopovid. Growford Institute. Available at: http://landukraine.com.ua/news_post/analitychnadopovid-growford-institute-rynok-zemli-isnuiuchi-zahrozy-dlia-ukrainy-ta-neobkhidni-zapobizhnyky

[4] Khodakivska, O. V., Levek, R. (2018). Zemelni vidnosyny: poshuk balansu interesiv mizh derzhavnym rehuliuvanniam ta neoliberalizmom. Ekonomika APK, 6, 5-17.

[5] Nepochatenko, O. O., Kolotukha, S. M., Borovyk, P. M., Huzar, B. S. (2017). Zemelni vidnosyny ta finansovi aspekty yikh rozvytku. Ekonomika APK, 6, 42-52.

[6] Cai, M., Murtazashvili, I., Murtazashvili, J. (2019). The politics of land property rights. Journal of Institutional Economics, 16 (2), 151-167. doi: http://doi.org/10.1017/s1744137419000158

[7] Belesky, P. (2015). Towards a New Political Economy of Food: State Capitalism and the Emergence of New Mercantilism in the Global Food System. The University of Warwick: New Directions in International Political Economy. Available at: https:// doi.org/10.2139/ssrn.3473843

[8] Banerdzhi, A., Duflo, E. (2018). Ekonomika bidnosti. Yak zvilnyty svit vid zlydniv. Kyiv: Nash format, 312.

[9] Marshall, A. (1890). Principles of Economics. Available at: http://files.libertyfund.org/files/1676/Marshall_0197_EBk_v6.0.pdf

[10] Troian, I. (2010). Derzhavnyi suverenitet yak politolohichna katehoriia: sutnist, kharakterystyky, osoblyvosti transformatsii. Ukrainska natsionalna ideia: realii ta perspektyvy rozvytku, 22, 130-136.

[11] Batterbury, S. P. J., Ndi, F.; Binns, J. A., Lynch, K., Nel, E. (Eds.) (2018). Land grabbing in Africa. The Routledge Handbook of African Development. London: Routledge, 573-582. Available at: https://www.researchgate.net/publication/322790095 Land-grabbing_in_Africa

[12] Yermolenko, V. M., Kurylo, V. I., Kyryliuk, T. S. (2007). Pravove zabezpechennia okhorony ta ratsionalnoho vykorystannia zemelnykh resursiv. Kyiv: Mahistr. XXI st., 248.

[13] Fedorov, M. M. (2009). Transformatsiia zemelnykh vidnosyn do rynkovykh umov. Ekonomika APK, 3, 4-18.

[14] OON: Konflikty v sviti vybukhaiut zazvychai cherez pryrodni resursy (2014). Available at: https://dt.ua/WORLD/oon-konflikti-v-sviti-vibuhayut-zazvichay-cherez-prirodni-resursi-155895_html

[15] Pankiv, Z. P. (2008). Zemelni resursy. Vydavnychyi tsentr LNU imeni Ivana Franka, 272.

[16] Kene, F., Tiurgo, A. R. Zh., Diupon de Nemur, P. S. (2008). Fiziokraty. Izbrannye ekonomicheskie proizvedeniia. Eksmo, 1200.

[17] Petti, U. (1993). Traktat o nalogakh i sborakh. SHedevry mirovoi ekonomicheskoi mysli. Vol. 2. Petrokommerts, 320.

[18] Smit, A. (1962). Issledovanie o prirode i prichinakh bogatstva narodov. Moscow: Sotsekgiz, 684.

[19] Rikardo, D. (1955). Nachala politicheskoi ekonomii i nalogovogo oblozheniia. Sochineniia. Vol. 1. Moscow: Gosudarstvennoe izdatelstvo politicheskoi literatury, 860 . 
[20] Mill, Dzh. S. (1896). Osnovaniia politicheskoi ekonomii s nekotorymi iz ikh primenenii v obschestvennoi filosofii. Kyiv: Tipografiia I. I. Chokolova, 866.

[21] Marks, K. (1983). Kapital. Kritika politicheskoi ekonomii. Vol. 1. Kniga 1: protsess proizvodstva kapital. Moscow: Politizdat, 592 .

[22] Marks, K. Nischeta filosofii. Otvet na «Filosofiiu nischety» g-na Prudona. Available at: https://www.esperanto.mv.ru/ Marksismo/Misere/index.html

[23] Halchynskyi, A. S. (2010). Ekonomichna metodolohiia. Lohika onovlennia. Kyiv: ADEF-Ukraina, 572.

[24] Semiuels, U. Dzh.; Afanaseva, V. S., Entova, R. M. (Eds.) (1981). Ideologiia v ekonomicheskom analize. Sovremennaia ekonomicheskaia mysl. Seriia: «Ekonomicheskaia mysl Zapada». Moscow: Progress, 513.

[25] Fridman, M., Fridman, R. (2017). Kapitalizm i svoboda. Kyiv: Nash format, 216.

[26] Erkhard, L. (1993). Polveka razmyshlenii. Rechi i stati. Moscow, 608.

[27] Kouz, R. (2007). Firma, rynok i pravo. Moscow: Novoe izdatelstvo, 224.

[28] Duglas, N. (1997). Instituty, institutsionalnye izmeneniia i funktsionirovanie ekonomiki. Moscow, 320.

[29] De Soto, E. (2012). Zahadka kapitalu. Chomu kapitalizm peremahaie lyshe na Zakhodi i nide bilshe. Kyiv: Nika-Tsentr, 232. 